\title{
Assessment of Pharmacists' Views on Biosimilar Naming Conventions
}

\author{
Sara Fernandez-Lopez, PhD, MBA; Denise Kazzaz, BA; Mohamed Bashir, MHA; and \\ Trent McLaughlin, BSc, PhD
}

\begin{abstract}
BACKGROUND: As the date for the introduction of biosimilars in the United States approaches, questions remain regarding the naming, coding, and approval process for these agents that will need to be carefully considered.

OBJECTIVES: To (a) ascertain pharmacists' awareness of and comfort level with biosimilars and (b) determine the impact of identical or different nonproprietary names on pharmacists' confidence in substituting interchangeable biologics.
\end{abstract}

METHODS: The Academy of Managed Care Pharmacy, the American Pharmacists Association, and the American Society of Health-System Pharmacists fielded a survey to their membership or a partial segment of their membership. The survey consisted of 2 sections: (1) current processes for reporting biologics being dispensed and (2) familiarity and preferences regarding biosimilars.

RESULTS: A substantial majority (70.1\%) of respondents reported regularly using National Drug Code numbers as the identifier for biological products dispensed to patients; however, $10.4 \%$ of respondents reported using either the nonproprietary name or the Healthcare Common Procedure Coding System code as the identifier. When presented with 3 scenarios for naming conventions of interchangeable biosimilars and asked to rate their level of confidence ( $1=$ not confident, $5=$ very confident) to substitute, $74.6 \%$ of pharmacists indicated that they would be confident or very confident in substituting an interchangeable biosimilar with the reference product if both shared the same active ingredient or nonproprietary name of the reference biologic; $25.3 \%$ of pharmacists were confident in substituting when the nonproprietary name is not shared with the biologic; and $37.3 \%$ of pharmacists expressed confidence in substituting when the biologic and biosimilar product did not share the same nonproprietary name because of a prefix or suffix.

CONCLUSIONS: The imminent entry of biosimilars into the U.S. market highlights the need to carefully evaluate current processes of identification, reporting, and recording of the biological products dispensed. The results of this survey indicate that the ultimate decision on the naming convention for biosimilars may influence dispensing pharmacists, with the majority of respondents being most comfortable with biosimilars having the same nonproprietary name as the reference biologic.

J Manag Care Spec Pharm. 2015;21(3):188-95

Copyright @ 2015, Academy of Managed Care Pharmacy. All rights reserved.

\section{What is already known about this subject}

A new approval pathway for biosimilars has been established, and applications have been submitted to the FDA. One or more biosimilar agents may launch in the United States in 2015.
Products will be similar to reference biologics, not exact replicas, given the intricacy of their molecular structure and the complexity of the production methods.

Potential skepticism from the public, including patients and health care professionals, remains regarding safety and efficacy of these new products.

\section{What this study adds}

Assessment of the impact of identical or different nonproprietary names on pharmacists' confidence in substituting interchangeable biologics.

Evaluation of whether current processes for information sharing and data recording are enough to differentiate the biologic used without the need for different nonproprietary names.

工 n July 2014, the U.S. Food and Drug Administration (FDA) accepted the first application for approval of a biologic under the new biosimilar pathway created in the Biologics Price Competition and Innovation Act, which was introduced as part of the Affordable Care Act. Because of the complexity of biologic products and the complexity of their manufacturing processes, biosimilars are never expected to be exact replicas of the reference product but are "highly similar to the reference product notwithstanding minor differences in clinically inactive components." "Thus, the naming and identification rules commonly applied to generics of small molecules have to be evaluated, considering the complexities of these biological products.

In Europe, Japan, Australia, and other markets, biosimilars have been in the market for over 7 years (Table 1). In the United States, the FDA has received at least 4 applications under the biosimilar pathway (section 351[k] of the Public Health Service Act). On July 24, 2014, Sandoz announced that the FDA had accepted its application for its biosimilar to Neupogen (filgras(im) ${ }^{2}$; on January 7, 2015, the FDA Oncologic Drugs Advisory Committee unanimously recommended its approval. ${ }^{3}$ In August 2014, Celltrion announced the filing of its application for FDA approval of its biosimilar to Remicade (infliximab), the first biosimilar monoclonal antibody to be filed through the new biosimilar pathway, ${ }^{4}$ and in December 2014, Hospira and Apotex filed applications for biosimilars to Epogen/Procrit (epoetin alfa) and Neulasta (pegfilgrastim), respectively., ${ }^{5,6}$

In the United States, the FDA has released draft guidance documents on the approval process and exclusivity requirements $^{7}$; however, a key question still remaining is how these 
TABLE 1 List of Biosimilar Products Approved by the EMA ${ }^{18}$

\begin{tabular}{|c|c|c|c|c|}
\hline $\begin{array}{l}\text { Nonproprietary } \\
\text { Name Substance }\end{array}$ & Medicine Name & Marketing Authorization Holder & $\begin{array}{c}\text { Year of } \\
\text { Approval }\end{array}$ & $\begin{array}{l}\text { Reference Product } \\
\text { (Innovator) }\end{array}$ \\
\hline Epoetin alfa & Abseamed & MEDICE Arzneimittel Pütter GmbH \& Co. KG & 2007 & \multirow{5}{*}{$\begin{array}{c}\text { Eprex/Erypo } \\
\text { (Janssen-Cilag GmbH) }\end{array}$} \\
\hline Epoetin alfa & Binocrit & Sandoz GmbH & 2007 & \\
\hline Epoetin alfa & Epoetin Alfa Hexal & Hexal AG & 2007 & \\
\hline Epoetin zeta & Retacrit & Hospira UK Limited & 2007 & \\
\hline Epoetin zeta & Silapo & STADA Arzneimittel AG & 2007 & \\
\hline Filgrastim & Accofil & Accord Healthcare Ltd & 2014 & \multirow{9}{*}{ Neupogen (Amgen) } \\
\hline Filgrastim & Biograstim & AbZ-Pharma GmbH & 2008 & \\
\hline Filgrastim & Filgrastim Hexal & Hexal AG & 2009 & \\
\hline Filgrastim & Filgrastim ratiopharma & Ratiopharm GmbH & 2008 & \\
\hline Filgrastim & Grastofil & Apotex Europe BV & 2013 & \\
\hline Filgrastim & Nivestim & Hospira UK Ltd. & 2010 & \\
\hline Filgrastim & Ratiograstim & Ratiopharm GmbH & 2008 & \\
\hline Filgrastim & Tevagrastim & Teva GmbH & 2008 & \\
\hline Filgrastim & Zarzio & Sandoz GmbH & 2009 & \\
\hline Follitropin alfa & Bemfola & Finox Biotech AG & 2014 & \multirow{2}{*}{$\begin{array}{c}\text { Gonal-F } \\
\text { (Merck Serono Europe Ltd) }\end{array}$} \\
\hline Follitropin alfa & Ovaleap & Teva Pharma BV & 2013 & \\
\hline Infliximab & Inflectra & Hospira UK Limited & 2013 & \multirow{2}{*}{$\begin{array}{c}\text { Remicade } \\
\text { (Janssen Biologics BV) }\end{array}$} \\
\hline Iinfliximab & Remsima & Celltrion Healthcare Hungary Kft. & 2013 & \\
\hline Insulin glargine & Abasria & Eli Lilly Regional Operations GmbH & 2014 & Lantus (Sanofi) \\
\hline Somatropin & Omnitrope & Sandoz GmbH & 2006 & Genotropin (Pfizer) \\
\hline Somatropin & Valtropina & Biopartners GmbH & 2006 & Humatrope (Eli Lilly) \\
\hline
\end{tabular}

aWithdrawn after approval.

EMA = European Medicine Agency

biosimilar products will be named. Proponents of using the same international nonproprietary name (INN), or generic name, highlight the fact that having different INNs would cause confusion among prescribers, possibly creating an artificial barrier in the adoption of biosimilars, and could affect the substitution of interchangeable biosimilars. ${ }^{8}{ }^{89}$ Proponents suggest that the use of National Drug Code (NDC) numbers and other product identifiers are sufficient for postmarketing surveillance. However, opponents to a single INN for reference and biosimilar products point to the need to reduce the likelihood of inadvertent and inappropriate product switching and of the ability to clearly identify which product is used for postmarketing safety and effectiveness monitoring. ${ }^{10,11}$

Given the importance of this issue, we conducted a survey among the Academy of Managed Care Pharmacy (AMCP), the American Pharmacists Association (APhA), and the American Society of Health-System Pharmacists (ASHP) members to understand the following: (a) the current processes to report dispensing information to other stakeholders (prescribers, payers, patients); (b) the dispensing information recorded in the patient record for biologics; and (c) how different naming options for biosimilars may influence pharmacists' likelihood of product substitution for interchangeable biosimilars.

In this article, we describe different options proposed in the United States and adopted in other parts of the world for biosimilar naming, analyze the value of each option, and report our survey findings on pharmacists' views on biosimilars naming conventions.

\section{Naming of Pharmaceuticals}

The World Health Organization (WHO) determines INNs for all marketed therapeutic products. INNs provide global names to drugs to prevent confusion with the use of multiple nonproprietary names in different countries. An INN is specific to a given defined substance regardless of the manufacturer. In the case of small molecules, the active substance in the original product and all subsequent generics share the same INN (e.g., acetaminophen), although nonactive ingredients may vary. As of now, biological substances are assigned INNs following the same general principles that apply to all INNs, while accounting for the specific complexities of biologics. For nonglycosylated proteins that share the same protein sequence as the originator, the same INN has been assigned so far (e.g., filgrastim). For more complex glycosylated proteins, the INN program introduced a second word representing a Greek letter to differentiate between different glycoform profiles (e.g., epoetin alfa and epoetin zeta).

Even though the WHO determines INNs, each regulatory authority decides whether to adopt the INN in their specific market. In the United States, the United States Adopted Name (USAN) council proposes and selects most generic names, 
called USAN in the United States, after consultation with the WHO-INN program. ${ }^{12}$ Since the FDA has representation in the USAN, there is a strong collaboration among both groups, USAN council and FDA, when selecting a nonproprietary name. ${ }^{13}$ Trade names in the United States are proposed by manufacturers and ultimately approved or rejected by the FDA. ${ }^{14}$

In the case of biosimilars, different regulatory authorities have followed different approaches in naming these new biologics. For example, an epoetin alfa registered in Europe with the INN "epoetin alfa" was later introduced in Australia with the generic name "epoetin lambda" to differentiate it from the original biologic..$^{15}$

To avoid confusion and allow a more comprehensive harmonized approach, different regulatory authorities requested that the WHO develop a global naming scheme for biosimilars. Under this voluntary scheme, the WHO INN Expert Group would develop a biologic qualifier (BQ) for all biological substances. The BQ, a 4-letter code assigned at random, would identify the manufacturer, as well as the manufacturing site, so pharmacovigilance can be guaranteed, as it would allow a global framework, while still differentiating production at 2 different sites. ${ }^{15}$

In the United States, the FDA has not released any guidance on biosimilar naming, despite previous requests. ${ }^{16}$ Different groups have laid out their reasons supporting their different positions. Through our survey, we aimed to understand pharmacists' perspectives on the issue, specifically as it relates to their current processes of data sharing with other stakeholders (providers, payers, patients) and how naming of biosimilars may influence their likelihood of substitution for interchangeable biologics.

\section{Methods}

To obtain input from pharmacists on their level of awareness and preferences concerning naming conventions of biosimilars, an online survey was fielded in November and December 2014 to the membership, or a cross-section of the membership, of 3 associations that represent pharmacists across the United States: AMCP, APhA, and ASHP.

The online survey was sent to all members of the AMCP and ASHP, as well as members of the Government Affairs Committee and Biosimilar Taskforce $(n=21)$ of the APhA. Participants were not excluded or terminated from the survey based on any of their responses. A combined total of 93 respondents participated in the survey.

Pharmacists were asked to identify the type of organization in which they are currently employed (Table 2). Based on their answers, participants were categorized into 3 main categories: (1) dispensing organizations; (2) managed care organizations, pharmacy benefit managers (PBMs), and consultants; and (3) manufacturers. If respondents indicated "other" as their classification, their open-ended responses were used to categorize them into 1 of the 3 organization types.

\section{TABLE 2 Characteristics of Survey Participants}

\begin{tabular}{|c|c|c|}
\hline Type of Pharmacy or Organization & $\%(n)$ & New Classification \\
\hline Managed care & $45.2(42)$ & $\begin{array}{l}\text { Managed care/PBM/ } \\
\text { consultant }\end{array}$ \\
\hline Hospital & $14.0(13)$ & Dispensing organizations \\
\hline Manufacturer & $12.9(12)$ & Manufacturer \\
\hline Specialty & $3.2 \quad(3)$ & Dispensing organizations \\
\hline Clinic & $1.0 \quad(1)$ & Dispensing organizations \\
\hline Independent & $1.0 \quad(1)$ & Dispensing organizations \\
\hline Pharmacy small chain & $1.0 \quad(1)$ & Dispensing organizations \\
\hline Pharmacy large chain & $1.0 \quad(1)$ & Dispensing organizations \\
\hline $\begin{array}{l}\text { Other: retail and hospital (1), VA (1), } \\
\text { federal facility (1), IDN (1), ACO (1), } \\
\text { LTC (1), home infusion (1) }\end{array}$ & $7.5 \quad(7)$ & Dispensing organizations \\
\hline $\begin{array}{l}\text { Other: consultant/vendor (9), } \\
\text { PBM (2) }\end{array}$ & $11.8(11)$ & $\begin{array}{l}\text { Managed care/PBM/ } \\
\text { consultant }\end{array}$ \\
\hline Other: pharmaceuticals & $1.0 \quad(1)$ & Manufacturer \\
\hline
\end{tabular}

$A C O=$ accountable care organization; $I D N=$ integrated delivery network; $L T C=$ long-term care; $P B M=$ pharmacy benefit manager; $V A=$ Veterans Administration.

The survey instrument was developed based on a previous assessment of pharmacists' views on generic medications. That instrument was modified to incorporate the particular issues related to receipt, storage, and dispensing of biosimilar agents. To assist in the aggregation of results but still allow for additional detail on specific issues, the survey included a mix of close-ended and open-ended questions.

Sample questions included the following: "Assuming it would be permissible to do so, what would be your level of confidence to substitute an interchangeable biosimilar for a reference biologic in the following circumstances? Rank your level of confidence on a scale of 1 to 5 , with 1 being not confident and 5 being very confident," and "If a prescription was written ambiguously with a common root non-proprietary name (such as filgrastim), and the existing biosimilar and interchangeable products include that root name along with an additional unique suffix or prefix, how would you fill the prescription?".

Association members were given approximately 3 weeks to respond to the survey. Survey responses were aggregated and analyzed using SAS 9.4 (SAS Institute, Inc., Carey, NC). Since this is a descriptive analysis, aggregate results are presented as a percentage endorsing a particular response category; no comparisons were made to assess statistical significance. No patient information was included in this study nor were survey respondents identifiable at any point; therefore, institutional review board approval was not necessary.

\section{Results}

A total of 93 pharmacists submitted a response to the survey. Not all questions required responses, and some pharmacists elected to not answer every question. The demographics of survey respondents are summarized in Table 2 . The majority of 
FIGURE 1 Current Practices for Sharing Dispensing Information

A. Stakeholders with whom general dispensing information is shared (multiple selection allowed) (Percentage of respondents that shared dispensing information with these stakeholders)

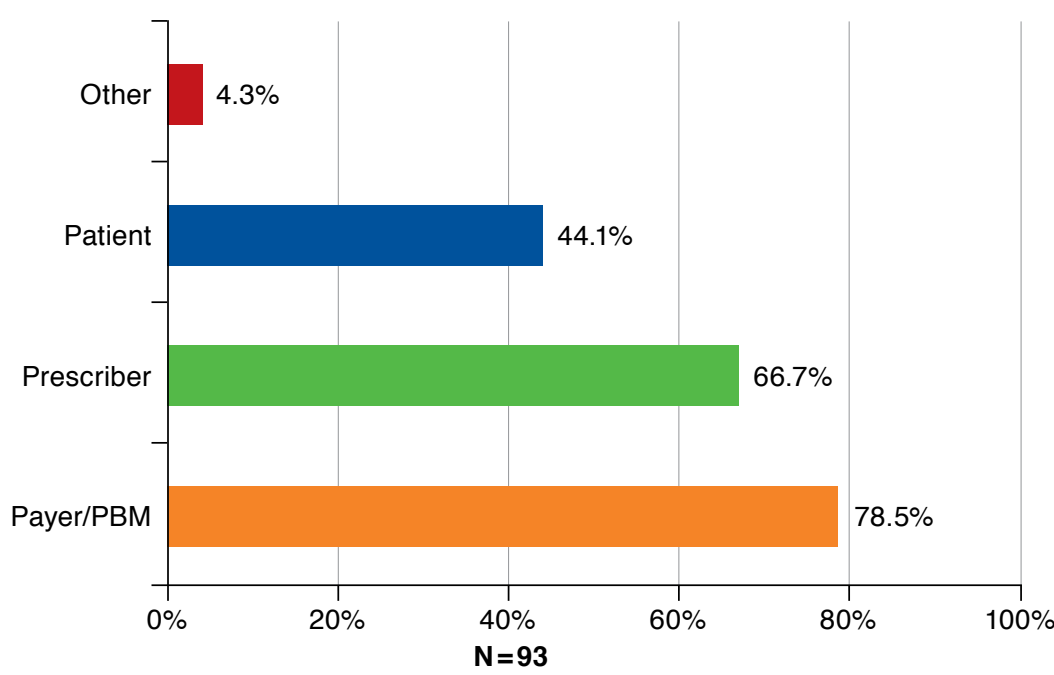

B. Methods of sharing dispensing information (multiple selection allowed)

(Percentage of respondents that used these methods of communication to share dispensing information)

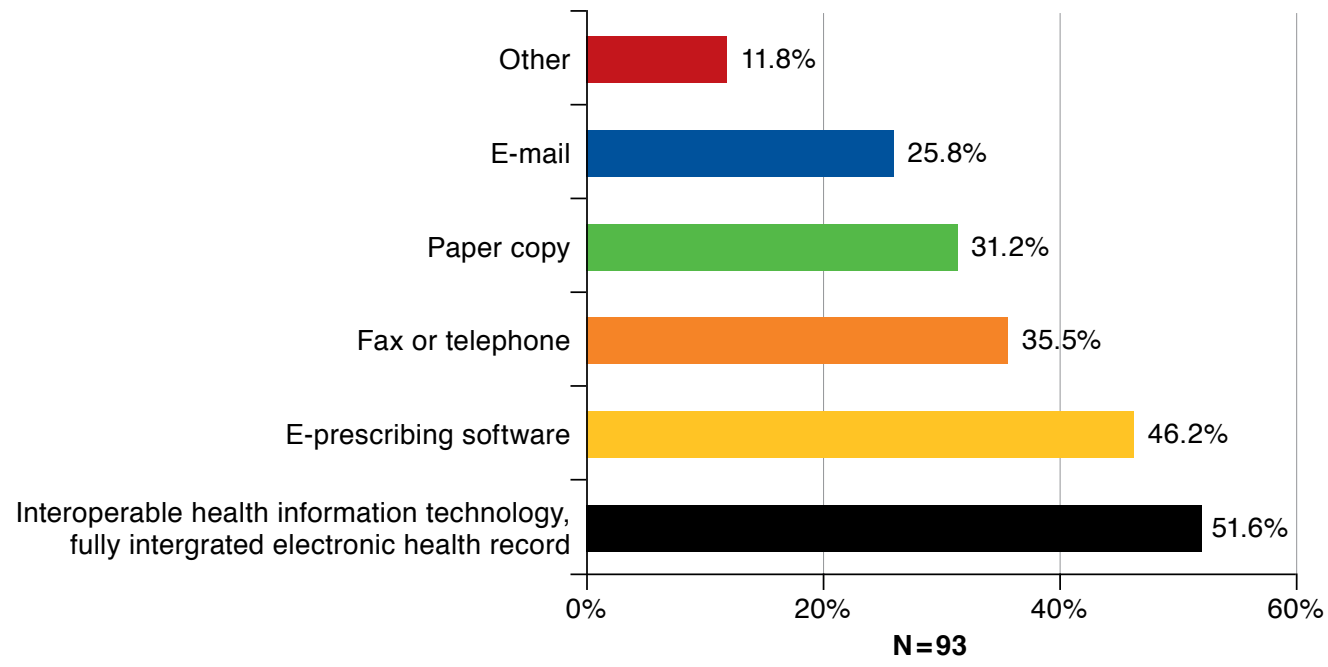

PBM= pharmacy benefit manager.

respondents represented managed care organizations (45.2\%), hospitals (14.0\%), or manufacturers (12.9\%).

When asked about current practices, pharmacists reported sharing information regarding dispensed products mainly with payers and PBMs (78.5\%) and prescribers (66.7\%). The methods used to share information included interoperable health information technology (51.6\%), e-prescribing software (46.2\%), fax or telephone (35.5\%), paper copy (31.2\%), or e-mail (25.8\%; Figure 1).
When asked about methods typically used to record what biologics were dispensed, pharmacists selected scanning a barcode that links to and populates a patient health record (24.7\%), typing the information into an electronic patient record $(23.4 \%)$, and selecting the product from a drop-down menu (23.4\%; Figure 2).

In most cases (76.6\%), the information recorded allowed for identification of which biologic was dispensed, either by the use of NDC numbers (70.1\%) or a combination of the 


\section{FIGURE 2 Methods to Record Which Biologic Product Was Dispensed to Patient $(\mathrm{N}=77)$}

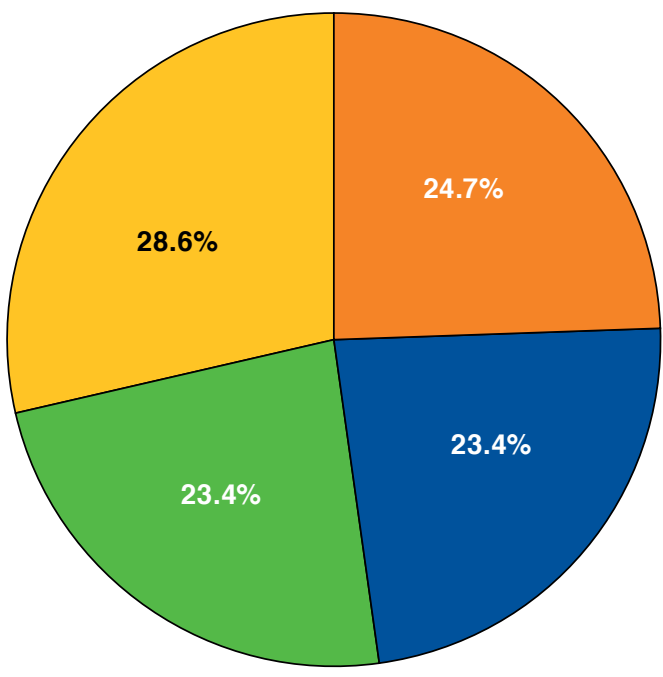

Scan a barcode that links to and populates a patient health record

- Select product from drop-down menu that has been prepopulated with information supplied by patient health system

Type information into electronic patient health record system Other ${ }^{\mathrm{a}}$

a Other responses (22) included the following: Not applicable/not dispensing (13), pharmacy system (3), National Drug Codes (2), proprietary software (1), articles (1), formulary selection (1), scan bar code for prescription products, manual entry for injectables (1).

nonproprietary name or Healthcare Common Procedure Coding System (HCPCS) code and the manufacturer or brand name (6.5\%; Table 3); however, in $10.4 \%$ of cases the information recorded did not include specific brand or manufacturer of the product, since only the HCPCS or nonproprietary name was recorded. This is in line with what has been documented before. ${ }^{17}$
Pharmacists were asked to rate their familiarity with biosimilars on a level of 1 to 5 , with 1 being the least familiar and 5 being the most familiar. Over half of the respondents (66.2\%) identified a familiarity level of 4 or 5 with biosimilars. The percentage of respondents indicating the same level of familiarity with interchangeable biosimilars fell to 50.6\%. Finally, $72.7 \%$ of respondents indicated an awareness level of 4 or 5 regarding whether biosimilars were being sold in other countries. Respondents representing managed care, PBMs and consultants, and dispensing organizations were fairly familiar with biosimilars $(69.0 \%$ and $68.0 \%$, respectively, indicated level 4 or 5) and fairly aware of biosimilars being sold in other countries $(76.2 \%$ and $76.0 \%$, respectively), while they were less familiar with interchangeable biologics (52.4\% and 60\%, respectively). Respondents from manufacturers were the least familiar of all, with $50.0 \%$ indicating a familiarity level of 4 or 5 with biosimilars and awareness of biosimilars being sold in other countries. Only $20.0 \%$ of respondents indicated familiarity with interchangeable biologics (Table 4).

When asked about their confidence in substituting interchangeable biologics under different naming scenarios, pharmacists felt most comfortable with a scenario in which the reference product and the biosimilar shared the same nonproprietary name, with 56 respondents (74.6\%) being confident or very confident. In a scenario with different nonproprietary names, only 19 (25.3\%) indicated a confidence level of 4 or 5 . Finally, in a third scenario in which reference products and biosimilars would not share a nonproprietary name because of a prefix or suffix, 28 (37.3\%) indicated a confidence level of 4 or 5 (Figure 3).

Lastly, when asked whether physician postdispensing notification requirements would affect their willingness to dispense an interchangeable biosimilar, $52.7 \%$ of respondents reported that such a notification requirement would not affect their likelihood to substitute; $19.4 \%$ of respondents indicated that it would make them less likely to substitute; and $23.7 \%$ were not sure how this would affect their substitution practices. Only $4.3 \%$ of pharmacists felt that a notification requirement would make them more likely to substitute (Figure 4).

TABLE 3 Information Recorded When a Biologic Product Is Dispensed

\begin{tabular}{|c|c|c|c|c|c|c|c|c|}
\hline \multirow[b]{3}{*}{ Type of Respondent } & \multirow{2}{*}{\multicolumn{2}{|c|}{ NDC Recorded }} & \multicolumn{4}{|c|}{ NDC Not Recorded } & \multirow{2}{*}{\multicolumn{2}{|c|}{ Not Dispensing }} \\
\hline & & & \multicolumn{2}{|c|}{$\begin{array}{c}\text { Nonproprietary Name } \\
\text { or HCPCS Code with } \\
\text { Manufacturer or Brand Name }\end{array}$} & \multicolumn{2}{|c|}{$\begin{array}{c}\text { Nonproprietary Name } \\
\text { or HCPCS Code with No } \\
\text { Manufacturer or Brand Name }\end{array}$} & & \\
\hline & $\%$ & (n) & $\%$ & $(n)$ & $\%$ & $(\mathrm{n})$ & $\%$ & $(\mathrm{n})$ \\
\hline All respondents $(\mathrm{N}=77)$ & 70.1 & $(54)$ & 6.5 & $(5)$ & 10.4 & $(8)$ & 13.0 & $(10)$ \\
\hline Dispensing organizations $(n=25)$ & 72.0 & $(18)$ & 16.0 & (4) & 5.5 & (3) & \multicolumn{2}{|c|}{0} \\
\hline Managed care/PBM/consultant $(n=42)$ & 69.0 & $(29)$ & 2.4 & $(1)$ & 9.5 & $(4)$ & 19.0 & $(8)$ \\
\hline Manufacturers $(n=10)$ & 70.0 & $(7)$ & \multicolumn{2}{|c|}{0} & 10.0 & $(1)$ & 20.0 & $(2)$ \\
\hline
\end{tabular}

HCPCS = Healthcare Common Procedure Coding System; NDC= National Drug Code; PBM= pharmacy benefit manager 
TABLE 4 Familiarity of Survey Respondents with Biosimilars

\begin{tabular}{|c|c|c|c|c|c|c|}
\hline \multirow[b]{2}{*}{ Respondent Type } & \multicolumn{2}{|c|}{$\begin{array}{c}\text { Familiarity with Biosimilars } \\
\text { (Level } 4 \text { or } 5)\end{array}$} & \multicolumn{2}{|c|}{$\begin{array}{c}\text { Familiarity with Interchangeable } \\
\text { Biosimilars (Level } 4 \text { or } 5 \text { ) }\end{array}$} & \multicolumn{2}{|c|}{$\begin{array}{c}\text { Awareness of Biosimilars Being } \\
\text { Sold Outside United States } \\
\text { (Level } 4 \text { or } 5)\end{array}$} \\
\hline & $\%$ & $(\mathrm{n})$ & $\%$ & (n) & $\%$ & (n) \\
\hline All respondents $(\mathrm{N}=77)$ & 66.2 & $(51)$ & 50.6 & (39) & 72.7 & $(56)$ \\
\hline Dispensing organizations $(n=25)$ & 68.0 & (17) & 60.0 & (15) & 76.0 & (19) \\
\hline Managed care/PBM/consultant $(n=42)$ & 69.0 & $(29)$ & 52.4 & $(22)$ & 76.2 & $(32)$ \\
\hline Manufacturers $(n=10)$ & 50.0 & $(5)$ & 20.0 & $(2)$ & 50.0 & $(5)$ \\
\hline
\end{tabular}

\section{FIGURE 3 Confidence of Survey Respondents in Substituting Interchangeable Biosimilars}

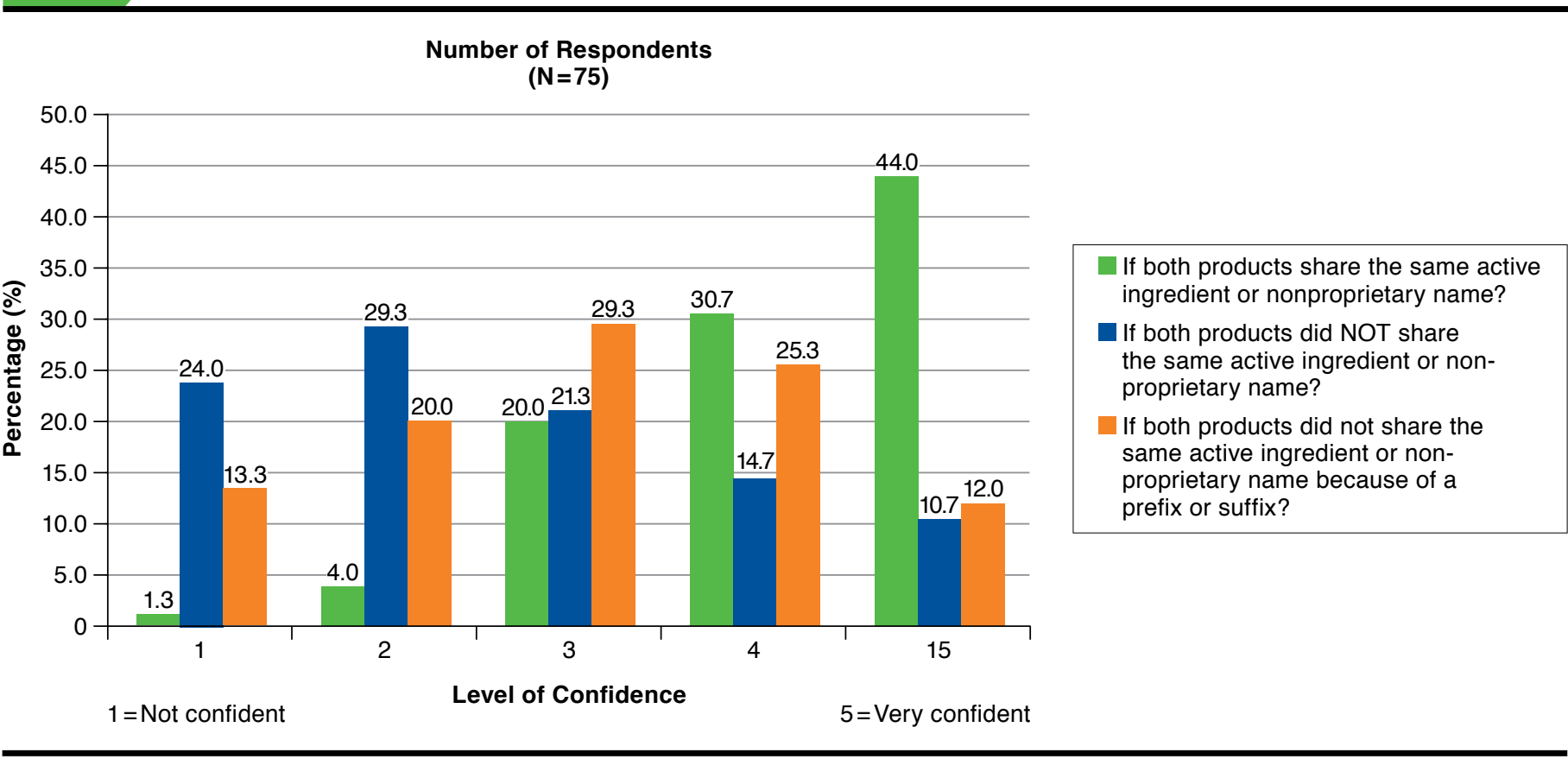

\section{Discussion}

As the United States prepares for the introduction of the first biosimilars and interchangeable biologics, the debate on the appropriate naming conventions for biosimilars continues. Both sides of the debate have compelling arguments for their positions. On one hand, there is the need for adequate identification of product dispensed for pharmacovigilance efforts; on the other hand, there needs to be assurance that biosimilars do not encounter artificial barriers to their adoption. The WHO proposal for development of a BQ that identifies the manufacturer and site of production, but still preserves the same INN for biosimilars and reference biologics, could be a potential solution for the naming of biosimilars.
While $66.2 \%$ of respondents indicated a high level of familiarity (level 4 or 5 , with 5 being very familiar) with biosimilars, only $50.6 \%$ of pharmacists reported the same level of familiarity with interchangeable biosimilars. The naming convention selected for biosimilars will play a pivotal role in the substitution practices of interchangeable biosimilars, given that most pharmacists have the highest level of confidence of substitution only when the interchangeable biosimilar and reference product share the same active ingredient or nonproprietary name.

\section{Limitations}

Limitations to this analysis include the lack of temporal data to determine if views have changed over time given the increased 


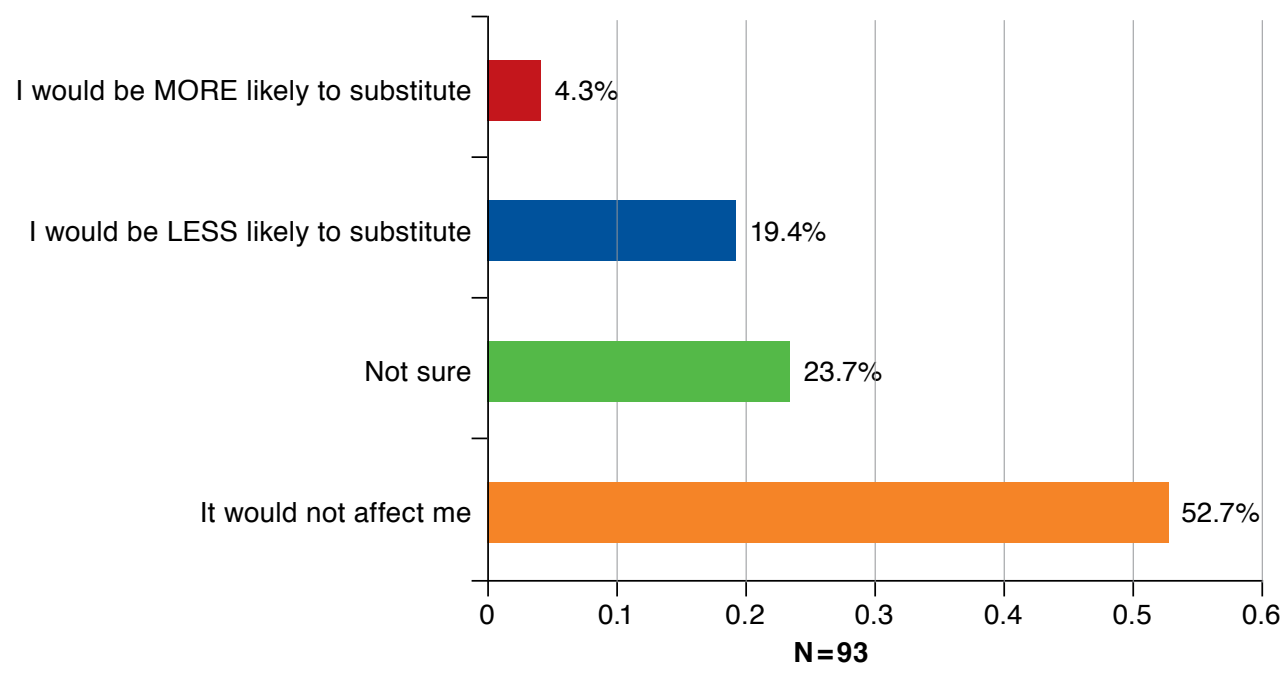

exposure to these topics in health-related publications and the lack of generalizability given the low overall response rate.

\section{Conclusions}

The results of the survey used in this analysis highlight the importance of the upcoming FDA decision on how biosimilars will be named. On one hand, results indicate that current processes for identifying biologics may not be sufficient if biosimilars and reference products share the same INN and HCPCS codes. On the other hand, different INNs may influence pharmacists' likelihood to substitute interchangeable biologics and prevent full adoption of biosimilars in the market, since most pharmacists indicated feeling confident or very confident with biosimilar substitution only when the interchangeable biologic and the reference product shared a generic or nonproprietary name.

In addition, based on the lower levels of familiarity with interchangeable biologics and how naming of biosimilars may influence their behavior, this survey also indicates that pharmacists, who will be on the front lines when it comes to dispensing biosimilars, will require substantial education on biosimilars and interchangeable biosimilars prior to the launch of the first agent in the United States. This education should focus on 3 areas: (1) instances where substitution is allowed according to FDA approval (as a biosimilar or interchangeable biologic); (2) appropriate recording of a biologic dispensed for pharmacovigilance efforts; and (3) notification requirements driven by specific state laws.

\section{Authors}

SARA FERNANDEZ-LOPEZ, PhD, MBA, is Director, Reimbursement Strategy, Xcenda, San Bruno, California, and MOHAMED BASHIR, MHA, is Manager, Market Insights, Xcenda, Charlotte, North Carolina. DENISE KAZZAZ, BA, is Director, Scientific Client Strategies, Xcenda, and TRENT MCLAUGHLIN, BSc, PhD, is Vice President, Scientific Client Strategies, Xcenda, Palm Harbor, Florida.

AUTHOR CORRESPONDENCE: Sara Fernandez-Lopez, PhD, MBA, Director, Reimbursement Strategy, Xcenda, AmerisourceBergen Specialty Group, 999 Bayhill Dr., San Bruno, CA 94066. E-mail: sara.fernandez@xcenda.com.

\section{DISCLOSURES}

The study instrument was developed in collaboration with AMCP leadership. The authors report no financial conflicts of interest related to the subject or products mentioned in this article.

Study concept and design were contributed by all the authors. Data collection was performed by Kazzaz, Fernandez-Lopez, and Bashir, and data were analysed by Bashir, Fernandez-Lopez, and Kazzaz. The manuscript was written by Fernandez-Lopez, Kazzaz, and Bashir and revised by McLaughlin, Fernandez-Lopez, Kazzaz, and Bashir.

\section{REFERENCES}

1. Patient Protection and Affordable Care Act. Public Law 111-148: 124 Statute 119. 111th Congress. March 23, 2010. Available at: http://beta.congress. gov/111/plaws/publ148/PLAW-11lpubl148.pdf. Accessed February 5, 2015.

2. Novartis Global. Media releases. FDA accepts Sandoz application for biosimilar filgrastim. July 24, 2014. Available at: http://www.novartis.com/newsroom/media-releases/en/2014/1835571.shtml. Accessed February 5, 2015. 
3. Novartis Global. Media releases. Sandoz biosimilar filgrastim recommended for approval by FDA Oncologic Drugs Advisory Committee. January 7, 2015. Available at: http://www.novartis.com/newsroom/media-releases/ en/2015/1885139.shtml. Accessed February 5, 2015.

4. Celltrion. What's New? Celltrion files for U.S. FDA approval of Remsima. August 11, 2014. Available at: http://www.celltrion.com/en/COMPANY/ notice_view.asp?idx $=456 \&$ code $=$ ennews $\&$ int NowPage $=1 \&$ menu_ num=\&align_year=all. Accessed February 5, 2015.

5. Apotex. Apotex announces FDA has accepted for filing its biosimilar application for pegfilgrastim. December 17, 2014. Available at: http://www. apotex.com/global/about/press/20141217.asp. February 5, 2015.

6. Hospira. Press release. Hospira submits new biologics license application to U.S. FDA for proposed epoetin alfa biosimilar. January 12, 2015. Available at: http://phx.corporate-ir.net/phoenix.zhtml?c=175550\&p=irolnewsArticle\&ID=2006860. Accessed February 5, 2015.

7. U.S. Food and Drug Administration. Biosimilars guidances. [A complete listing of the biosimilars guidances published between March 2013 and August 2014]. Available at: http://www.fda.gov/Drugs/ GuidanceComplianceRegulatoryInformation/Guidances/ucm290967.htm. Accessed February 5, 2015.

8. U.S. Food and Drug Administration. Generic Pharmaceutical Association-citizen petition. September 17, 2013. Available at: http://www. regulations.gov/\#!documentDetail;D=FDA-2013-P-1153-0001. Accessed February 5, 2015.

9. Letter to Commissioner Magaret A. Hamburg from multiple stakeholder organizations re consumers to the FDA on biosimilars INN. July 1, 2014. Available at: http://www.gphaonline.org/media/cms/Lttr_to_FDA_on_biosimilars_INN_June_2014.FINAL.pdf. Accessed February 5, 2015.

10. Dolinar R. Letter to Commissioner Margaret A. Hamburg re the Alliance for Safe Biologic Medicines to the Food and Drug Administration on naming of biologics. August 30, 2012. Available at: http://safebiologics.org/pdf/asbmnaming.pdf. Accessed February 5, 2015.

11. Saltonstall PL. Letter to Commissioner Margaret A. Hamburg re National Organization for Rare Disorder (NORD) and adoption of distinguishable names for biologics. June 3, 2014. Available at: http://rarediseases.org/advocacy/policy-statements/NORDSupportsSeparateNamingforBiosimilars.pdf. Accessed February 5, 2015.
12. American Medical Association. How to apply for a name. Available at: http://www.ama-assn.org/ama/pub/physician-resources/medical-science/ united-states-adopted-names-council/how-to-apply-for-usan.page. Accessed February 5, 2015.

13. American Medical Association. United States adopted names: latest news. Available at: http://www.ama-assn.org/ama/pub/physician-resources/ medical-science/united-states-adopted-names-council.page. Accessed February 5, 2015

14. U.S. Food and Drug Administration. Guidance for industry: contents of a complete submission for the evaluation of proprietary names. February 2010. Available at: http://www.fda.gov/downloads/drugs/guidancecomplianceregulatoryinformation/guidances/ucm075068.pdf. Accessed February 5, 2015.

15. World Health Organization. Biological qualifier: an INN proposal. INN Working Doc. 14.342. Revised draft July 2014. Available at: http://www.who. int/medicines/services/inn/bq_innproposal201407.pdf. Accessed February $5,2015$.

16. Wolgemuth L, Jeffries JA. Alexander, Hatch call on Burwell to immediately release guidance on biosimilar drugs. U.S. Senate Committee on Health, Education, Labor and Pensions. August 1, 2014. Available at: http:// www.help.senate.gov/newsroom/press/release/?id=d3a2624c-2410-4d08b76e-883592c3885a. Accessed on February 5, 2015.

17. AMCP Task Force on Biosimilar Collective Intelligence Systems. Utilizing data consortia to monitor safety and effectiveness of biosimilars and their innovator products. J Manag Care Spec Pharm. 2015;21(1):23-34. Available at: http://www.amcp.org/WorkArea/DownloadAsset.aspx?id=18903.

18. European Medicine Agency. European public assessment reports. Available at: http://www.ema.europa.eu/ema/index.jsp?curl=pages\%2Fmedi cines\%2Flanding\%2Fepar_search.jsp\&mid=WC0b0lac058001d124\&searc $\mathrm{hTab}=$ searchByAuthType\&alreadyLoaded=true\&isNewQuery=true\&status= Authorised\&status=Withdrawn\&status=Suspended\&status=Refused\&keyw ord=Enter+keywords\&searchType=name $\&$ taxonomyPath=\&treeNumber $=\&$ searchGenericType=biosimilars\&genericsKeywordSearch=Submit. Accessed February 5, 2015. 